\title{
Effects of Chiral Gold Nanoflowers on Polymerase Chain Reaction
}

Xiao Zhi, Xin Zhang, Peng Huang, Daxiang Cui*

Department of Bio-Nano Science and Engineering, National Key Laboratory of Nano/Micro Fabrication Technology, Key Laboratory for Thin Film and Microfabrication of Ministry of Education, Research Institute of Micro/Nano Science and Technology, Shanghai Jiao Tong University, Shanghai 200240, P. R. China

*Corresponding author: dxcui@sjtu.edu.cn; (Daxiang Cui) Tel.: +86-21-34206375; Fax: +86-21-34206886

Abstract

In this paper, we reported that chiral gold nanoflowers with the concentration of $0.08 \mathrm{mM}$ can enhance the specificity of polymerase chain reaction (PCR) and eliminate unspecific products, and the efficiency of PCR declines in some extent and the melt temperature of PCR products also raises slightly, which may be associated with the enhancement of the combining power of primers and ssDNA templates and the inner stability of dsDNA by chiral gold nanoflowers. The phenomena have great potential in applications such as ultrasensitive specific detection of DNA and SNPs.

Keywords:Chiral, Gold Nanoflowers, PCR, Real-Time PCR

Citation: X. Zhi, et al. Effects of Chiral Gold Nanoflowers on Polymerase Chain Reaction. Nano Biomed. Eng. 2011, 3(4), 256-259.DOI: 10.5101/ nbe.v3i4.p256-259.

\section{Introduction}

The polymerase chain reaction $(\mathrm{PCR})$ is one of the most popular techniques in modern molecular biological and medical sciences. A single nucleic acid molecule can be exponentially amplified in vitro [1].This remarkable amplification ability can be utilized for early stage diagnosis of cancers or infective diseases [2, 3].In the past decades, PCR technology was continuously optimized and ameliorated [4-8].However, the pursuit of ultra-sensitivity and high specificity of DNA detection never halted, because it is so important that target genes are detected at ultra-low levels during the early stages of diseases. With the development of nanotechnology, several reports showed that appropriate amount of nanomaterials added in PCR reagent can enhance the efficiency, sensitivity and specificity of PCR [9-15], and the specific mechanism seems to be supported by a number of studies $[5,9,16$, 17].But, these elucidations were thought to lack of further sufficient evidences and be controversial. In order to precisely evaluate the effects of nanoparticles on PCR, general PCR and Real-Time PCR were applied in our study.

\section{Experimental Section}

\subsection{Materials Source}

Primers (produced by Invitrogen life technologies), general PCR reagent (TaKaRa, Dalian, China), Real-Time reagent (SYBR ${ }^{\circ}$ Green Master Mixes, Invitrogen, USA), sterile deionized water (VEOLIA, ELGA-DI MK2, UK), Hepatitis Virus B (HBV) plasmids were kindly provided by Prof. Y.M. Wen (Fudan University, Shanghai, China).

\subsection{Preparation and characterization of chiral gold nanoflowers}

Chiral gold nanoflowers were prepared according to our previous paper and revised method [18], and characterized by high resolution transmission electron microscope(HR-TEM).

\subsection{General PCR}

PCR consisted of total reaction volumes of $25 \mu \mathrm{L}$, containing $1 \mu \mathrm{L}\left(12 \mathrm{ng} \cdot \mu \mathrm{L}^{-1}\right) \mathrm{HBV}$ plasmid DNA, 2.5 $\mu \mathrm{L} 10 \mathrm{x}$ PCR Buffer ( $\mathrm{Mg}^{2+}$ Plus), $2 \mu \mathrm{L}$ (2.5 mM) dNTP mixture, $0.125 \mu \mathrm{L}\left(5 \mathrm{U} \cdot \mu \mathrm{L}^{-1)}\right.$ Taq DNA Polymerase, $1 \mu \mathrm{L}$ $(10 \mu \mathrm{M})$ forward primer $1,1 \mu \mathrm{L}(10 \mu \mathrm{M})$ reverse primer 1, $5 \mu \mathrm{L}$ gold nanoflowers solution and $12.375 \mu \mathrm{L}$ sterile deionized water. PCR amplification was performed with Thermal Cycler (LongGene, L96C, China) under the following conditions: an initial denaturation at $95^{\circ} \mathrm{C}$ for 5 min and followed by 30 cycles of $94^{\circ} \mathrm{C}$ for $30 \mathrm{~s}, 53^{\circ} \mathrm{C}$ for $30 \mathrm{~s}$ and $72^{\circ} \mathrm{C}$ for $30 \mathrm{~s}$, finally polymerization at $72^{\circ} \mathrm{C}$ for 
$5 \min [19,20]$.

Forward Primer 1: 5'-ggacttctctcaattttctaggg-3'

Reverse Primer 1: 5'-tgaggcccactcccata-3'

\subsection{Real-Time PCR}

Effects of gold nanoflowers on polymerase chain reaction were evaluated accurately by Real-Time PCR with high sensitivity of detection. Real-Time PCR consisted of total reaction volumes of $20 \mu \mathrm{L}$, containing $10 \mu \mathrm{L} \mathrm{SYBR}^{\circledR}$ Green Master Mixes, $1 \mu \mathrm{L}\left(10^{5}\right.$ copy$\left.\cdot \mathrm{mL}^{-1}\right)$ HBV plasmid DNA, $1 \mu \mathrm{L}(10 \mu \mathrm{M})$ forward primer $2,1 \mu \mathrm{L}$ $(10 \mu \mathrm{M})$ reverse primer $2,4 \mu \mathrm{L}$ gold nanoflowers solution and $3 \mu \mathrm{L}$ sterile deionized water. PCR amplification was performed with Real-Time PCR detection system (BioRad, MyIQ5, USA) under the following conditions: an initial denaturation at $95^{\circ} \mathrm{C}$ for $10 \mathrm{~min}$ and followed by 40 cycles of $94^{\circ} \mathrm{C}$ for $30 \mathrm{~s}, 62^{\circ} \mathrm{C}$ for $30 \mathrm{~s}$, finally melt curves were analyed.

Forward Primer 2: 5'-accgaccttgaggcatact-3'

Reverse Primer 2: 5'-gcttggaggcttgaacagt-3'

\section{Results and Discussion}

\subsection{Characterization of chiral gold nanoflowers}

As shown in Fig. 1, prepared chiral gold nanoflowers were $60 \mathrm{~nm}$ in diameter, dispersed well in water solution, its final concentration is $1 \mathrm{mM}$.

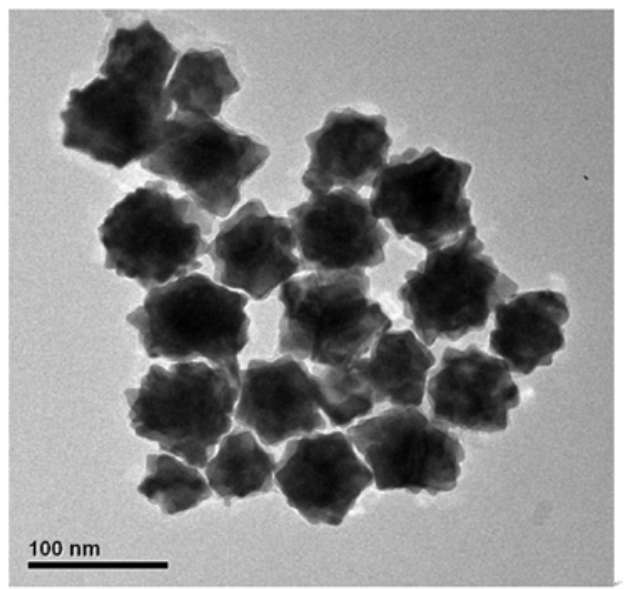

Fig. 1 Characterization of chiral gold nanoflowers by HR-TEM

\subsection{Analysis of general PCR products}

General PCR was applied to amplify a 395bp Hepatitis $B$ virus (HBV) fragments, and the products of PCR were analyzed by agarose gel electrophoresis. As shown in Fig. 2, the 395bp target fragments were all amplified, but the yield of lane 2 was so few that target fragments were barely detected. In contrast to lane 1, there were no significant differences of brightness of PCR products from lane 3 to lane 6 . However, unspecific fragments (between 200bp and 300bp) were observed distinctly from lane 1 to lane 6 expect lane 2, and the brightness of them increased gradually with the decline concentration of gold nanoflower solution from lane 3 to lane 6 .

At the same time, we found that the appropriate concentration of gold nanoflowers can eliminate the unspecific fragments from lane 2 to lane 5 as shown in Fig. 2, the lane 6 in Fig. 2 was the same as the lane 3 in Fig. 3. But, overfull gold nanoflowers added in PCR reagent could markedly inhibit the reaction of PCR in lane 2 and lane 3.

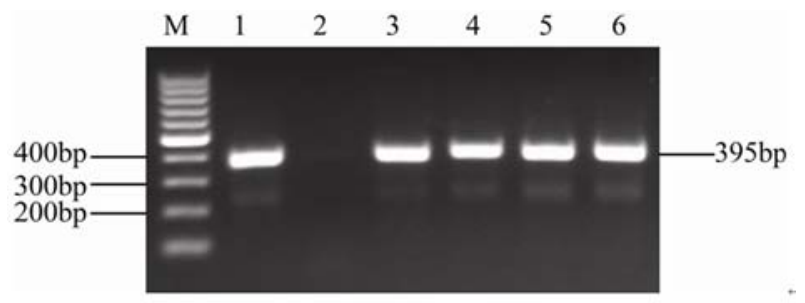

Fig. 2 The effects of concentration of gold nanoflowers on the efficiency of PCR: PCR was performed by amplifying a 395bp target fragments from HBV plasmids, and PCR products were analyzed by agarose gel electrophoresis $(1.2 \%)$. Lane $\mathrm{M}$ is for markers; lane 1: 0 ; lane 2: $0.2 \mathrm{mM}$; lane 3: $0.04 \mathrm{mM}$; lane 4: $8 \mu \mathrm{M}$; lane 5: $1.6 \mu \mathrm{M}$; lane 6: $0.32 \mu \mathrm{M}$.

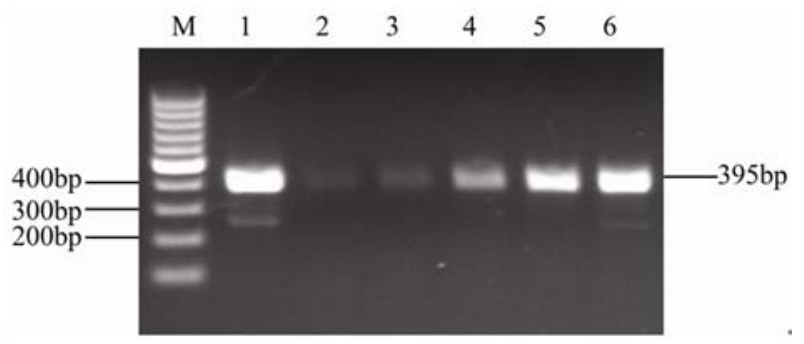

Fig. 3 The effects of concentration of gold nanoflowers on the specificity of PCR: lane $\mathrm{M}$ is for markers; lane 1: 0; lane 2: $0.2 \mathrm{mM}$; lane 3: $0.16 \mathrm{mM}$; lane 4: $0.12 \mathrm{mM}$; lane 5: $0.08 \mathrm{mM}$; lane 6: $0.04 \mathrm{mM}$.

\subsection{Analysis of Real-Time PCR products}

Real-Time PCR was applied to amplify a $189 \mathrm{bp}$ Hepatitis B virus(HBV) fragments [21]. The concentrations of gold nanoflowers used in study were $0.02 \mathrm{mM}, 0.04 \mathrm{mM}$ and $0.06 \mathrm{mM}$. Each sample was detected repeatedly in two times as displayed in Fig. 4. The green line indicated a control group without gold nanoflowers. Their $\mathrm{Ct}$ values were respectively 19.70 , 20.51, 20.89, 22.40, 22.29, 23.72 and 23.51(Fig. 4). It was noticeable that the reactions of PCR with gold nanoflowers were inhibited in contrast with control group. With the increase of concentration of gold nanoflowers, the inhibition effects of PCR were more markedly enhanced.

The analysis of melt curve of Real-Time PCR products was shown: their melt temperature values were respectively $78.00^{\circ} \mathrm{C}, 78.50^{\circ} \mathrm{C}, 78.50^{\circ} \mathrm{C}, 79.00^{\circ} \mathrm{C}$, $78.50^{\circ} \mathrm{C}, 79.00^{\circ} \mathrm{C}$ and $78.50^{\circ} \mathrm{C}$, and the peak height values were respectively $30.24,27.25,27.05,23.51,24.58$, 21.65 and 18.10 (Fig. 5). We found that the melt temperature ascended slightly and peak height declined obviously.Electrophoresis pattern of Real-Time PCR products demonstrated that single $189 \mathrm{bp}$ products were obtained(Fig. 6). 
http://nanobe.org

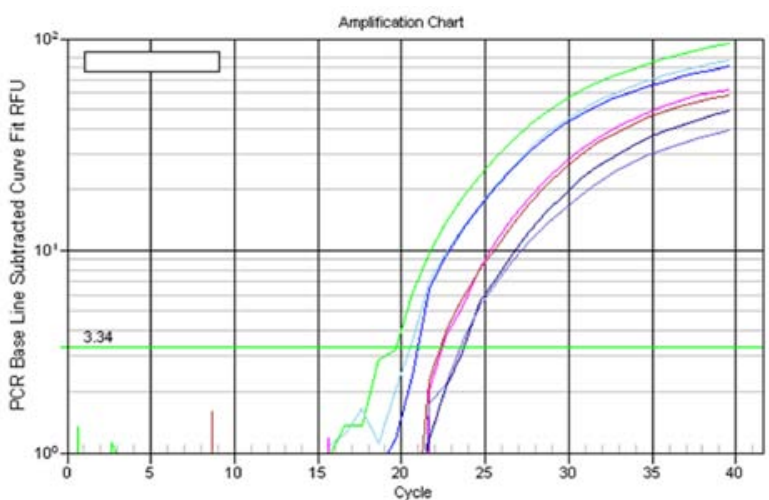

Fig. 4 Amplification chart of a 189bp fragments by Real-Time PCR: The concentration of gold nanoflowers: $0,0.02 \mathrm{mM}, 0.04 \mathrm{mM}$ and $0.06 \mathrm{mM}$.

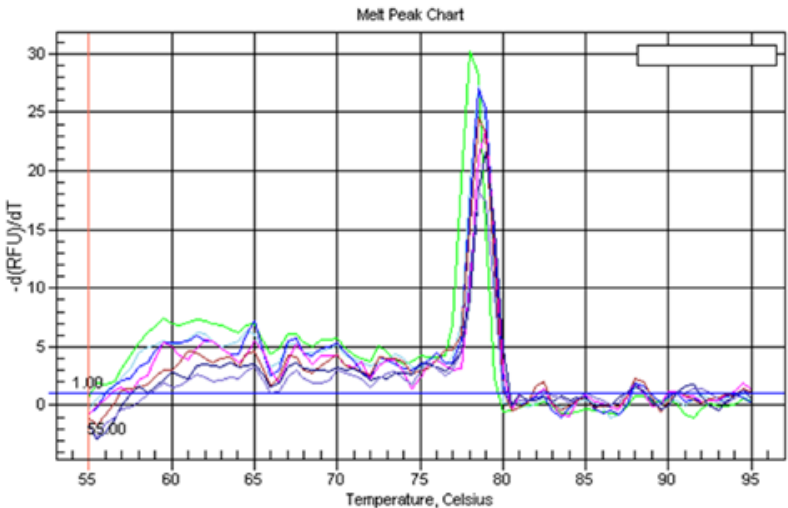

Fig. 5 Melt peaks chart of Real-Time PCR products. The concentration of gold nanoflowers: $0,0.02 \mathrm{mM}, 0.04 \mathrm{mM}$ and $0.06 \mathrm{mM}$.

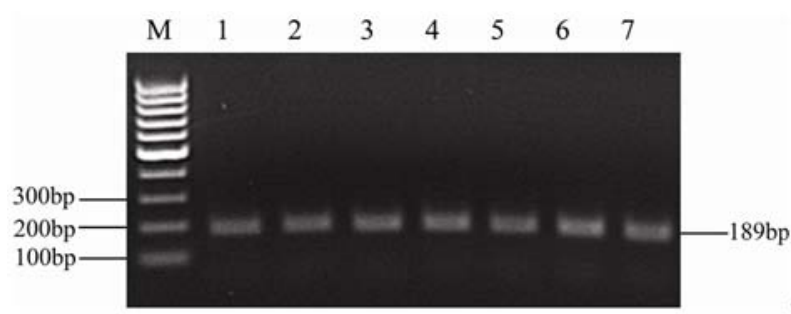

Fig. 6 Electrophoresis pattern of Real-Time PCR products: a 189bp target fragments were amplified from HBV plasmids, and the products were analyzed by agarose gel electrophoresis $(1.2 \%)$. Lane $\mathrm{M}$ is for markers; lane 1: 0; lanes 2, 3: $0.02 \mathrm{mM}$; lanes 4, 5: $0.04 \mathrm{mM}$; lane 6, 7: $0.06 \mathrm{mM}$.

\section{Conclusion}

In summary, we found that gold nanoflowers with 60 $\mathrm{nm}$ in diameter of $0.08 \mathrm{mM}$ can enhance the specificity of PCR and eliminate unspecific products. In spite of that, the presence of gold nanoflowers in PCR reagent will lead to inhibition of reaction of PCR in different degree, and the melt temperature of PCR products also raise slightly. We speculate that gold nanoflowers bind to ssDNAs much more strongly than to dsDNAs[16], which make the compounds of primers and ssDNA templates very hard to be untied, therefore the efficiency of PCR decreases. And gold nanoflowers make the ssDNAs and complementary ssDNAs combine firmly together and form dsDNAs, these dsDNAs are untied into ssDNAs only under higher temperature, thereby melt temperature ascend. The phenomena have great potential in applications such as ultrasensitive specific detection of DNA and SNPs.

\section{Acknowledgments}

This work was supported by Chinese Key Basic Research Project (2010CB933901and 2011CB933100), 863 Key Project (2007AA022004), New Century Excellent Talent of Ministry of Education of China(NCET-08-0350 and No.20070248050), National Major Scientific Projects for the Prevention and Control of HIV/AIDS and Viral Hepatitis of China (Nos. 2009ZX10004-311), Shanghai Science and Technology Fund (10XD1406100 and 1052nm04100).

\section{References}

1. Mullis KB and Faloona FA. Specific synthesis of DNA in vitro via a polymerase-catalyzed chain reaction. Methods Enzymol. 1987; 155:335-50.

2. Schochetman G, Ou CY, Jones WK. Polymerase chain reaction. J Infect Dis. 1988;158(6):1154-7.

3. Erlich HA. Polymerase chain reaction. J Clin Immunol. 1989; 9(6):437-447.

4. Innis MA, Gelfand DH. Optimization of PCRs. PCR protocols 1990;3-12.

5. Boon EM, Ceres DM, Drummond TG, Hill MG, Barton JK. Mutation detection by electrocatalysis at DNA-modified electrodes. Nature biotechnology. 2000;18(10):1096-1100.doi:10.1038/80301

6. Gaylord BS, Heeger AJ, BazanGC. DNA detection using water-soluble conjugated polymers and peptide nucleic acid probes. Proceedings of the National Academy of Sciences. 2002;99(17): 10954-10957.doi:10.1073/pnas.162375999

7. Whitcombe D., Theaker J.,Guy, SP, Brown T, Little S. Detection of PCR products using self-probing amplicons and fluorescence. Nat Biotech. 1999;17(8):804-807.doi:10.1038/11751

8. Mackay IM, Arden KE, Nitsche A. Real-time PCR in virology. Nucleic Acids Research. 2002;30(6):1292-1305. doi:10.1093/nar/30.6.1292

9 Li H, Huang J, Lv J, An H, Zhang X, Zhang Z. Nanoparticle PCR: Nanogold-Assisted PCR with Enhanced Specificity. Angewandte Chemie. 2005;117(32):5230-5233.doi:10.1002/ ange. 200500403

10.Li M, Lin YC, Wu CC, Liu HS.Enhancing the efficiency of a PCR using gold nanoparticles. Nucleic Acids Research. 2005; 33(21):e184.doi:10.1093/nar/gni183

11.Liu HH,Cao X, Yang Y, Liu MG, Wang YF. Array-based nano-amplification technique was applied in detection of hepatitis $\mathrm{E}$ virus. Journal of Biochemistry and Molecular Biology.2006; 39(3):247-252

12.Lin YC, Wu HL, Ieee. Nano-PCR: Breaking the bottom limit of the PCR denaturation temperature using nanogold, in 14th International Conference on Solid-State Sensors. Actuators and Microsystems.2007;199-200.

13.Zhang W, Yang T, Huang DM, Jiao K, Li GC. Synergistic effects of nano- $\mathrm{ZnO} / \mathrm{multi}$-walled carbon nanotubes/chitosan nanocomposite membrane for the sensitive detection of sequencespecific of PAT gene and PCR amplification of NOS gene. $J$ ournal of Membrane Science. 2008;325(1):245-251.doi:10.1016/ j.memsci.2008.07.038

14.Potůčková L, Franko Filip, Bambousková Monika, Drábe Petr. Rapid and sensitive detection of cytokines using functionalized gold nanoparticle-based immuno-PCR, comparison with immuno-PCR and ELISA. Journal of Immunological Methods. 2011;371(1-2):3847.doi:10.1016/j.jim.2011.06.012

15.Cui DX, Zhang H, Wang K, Gao F, Zhang XQ, Toru Asahi, et al. Gold Nanoparticles Enhance Efficiency of In Vitro Gene Transcription-Translation System. Nano Biomedicine and Engineering. 2011;3(1):120-125.doi:10.5101/nbe.v3i2.p120-125

16.Li HX, Lewis Rothberg. Colorimetric detection of DNA sequences based on electrostatic interactions with unmodified gold nanoparticles. Proceedings of the National Academy of Sciences of 
the United States of America. 2004;101(39):14036-14039. doi:10.1073/pnas.0406115101

17.Demers LM, Ostblom M, Zhang H, Jang NH, Liedberg B, Mirkin CA. Thermal desorption behavior and binding properties of DNA bases and nucleosides on gold. Journal of the American Chemical Society. 2002;124(38):11248-11249.doi:10.1021/ ja0265355

18.Pandoli O, Massi A, Cavazzini A, Spada GP, Cui DX. Circular dichroism and UV-Vis absorption spectroscopic monitoring of production of chiral silver nanoparticles templated by guanosine 5 '-monophosphate. Analyst. 2011;136(18):3713-3719.doi:10.1039/ clan15288b

19.Zhi Xiao, Liu QS, Zhang Xin, Zhang YX, Feng Jie, Cui DX. Quick Genotyping Detection of HBV by Giant Magnetoresistive Biochip combined with PCR and Line Probe Assay. Lab on a chip. 2011. doi:10.1039/c2lc20949g
20.Cui DX, Zhang H, Wang K, Gao F, Zhang XQ, Asahi T. Effects of single-walled carbon nanotubes on the polymerase chain reaction. Nanotechnology. 2004;15(1):154-157.doi:10.1088/09574484/15/1/030

21.Cui DX, Li Q, Huang P, Wang K, Kong YF, Zhang H .et al. Real time PCR based on fluorescent quenching of mercaptoacetic acid-modified CdTe quantum dots for ultrasensitive specific detection of nucleic acids. Nano Biomed Eng. 2010; 2(1):45-55.doi:10.5101/nbe.v2i1. p44-54

Copyright:(c) $2011 \mathrm{X}$. Zhi.et al. This is an openaccess article distributed under the terms of the Creative Commons Attribution License, which permits unrestricted use, distribution, and reproduction in any medium, provided the original author and source are credited. 